\title{
A Ricardian Analysis of the Impact of Climate Change on Latin
}

\section{American Farms ${ }^{1}$}

\author{
Niggol Seo \\ University of Aberdeen Business School, UK \\ and \\ Robert Mendelsohn \\ School of Forestry and Environmental Studies, Yale University, USA
}

\begin{abstract}
This study estimates the vulnerability of Latin American agriculture to climate change using a Ricardian analysis of both land values and net revenues. Examining a sample of over 2200 farms, the results indicate both land value and net revenue are sensitive to climate. Both small farms and large farms have a hill-shaped relationship with temperature. Estimating separate regressions for rainfed and irrigated farms reveals that rainfed farms are more sensitive to temperature but irrigated farms are more sensitive to precipitation. Examining the impacts from future climate change scenarios reveals that severe scenarios could reduce farm earnings by as much as $62 \%$ by 2100 whereas more moderate scenarios could reduce earnings by about 15\%. Small and large farms are equally sensitive to global warming. Land value and net revenue analyses produce quite similar results.
\end{abstract}

World Bank Policy Research Working Paper 4163, March 2007

The Policy Research Working Paper Series disseminates the findings of work in progress to encourage the exchange of ideas about development issues. An objective of the series is to get the findings out quickly, even if the presentations are less than fully polished. The papers carry the names of the authors and should be cited accordingly. The findings, interpretations, and conclusions expressed in this paper are entirely those of the authors. They do not necessarily represent the view of the World Bank, its Executive Directors, or the countries they represent. Policy Research Working Papers are available online at http://econ.worldbank.org.

\footnotetext{
${ }^{1}$ We thank Alfredo Albin, Irma Baquero, Luis José María Irias, Jorge González, Jorge Granados, Flavio Játiva, Bruno Llanfranco, Jorge Lozanoff, Raphael Pachico, and Roberto Velasco for their contribution to this project. We would also like to thank Emilio Ruz, Ariel Dinar and Flavio Avila for their support and leadership throughout this project. We also thank Bruce Dixon for his detailed and constructive advice. This project was funded by the Research Committee of the World Bank under the study 'Climate Change and Rural Development' that was tasked managed by Ariel Dinar.
} 


\title{
A Ricardian Analysis of the Impact of Climate Change on Latin
}

\author{
American Farms
}

\section{Introduction}

A growing number of scientific studies indicate that the world is warming and will continue to warm as the concentration of greenhouse gases rises in the future (Houghton et al. 2001). However, there remains considerable debate about how harmful climate change will actually be (McCarthy et al. 2001). This paper examines the climate sensitivity of agricultural production in Latin America (which is defined as the Western Hemisphere south of the United States). Agriculture in Latin America is already highly vulnerable because of high current temperatures and poor farmers. Further, agriculture is responsible for $8.6 \%$ of the GDP in Latin America (World Development Indicators 2004) and uses approximately one-third of the land area of the continent (World Resources 2005). There have been several country level agronomic studies of selected crops in Latin America, but there have been very few agro-economic studies. One notable exception is a Ricardian study of farmland values in Brazil (Mendelsohn et al. 2001) which indicated that farm land values are sensitive to climate.

This paper examines over 2200 farmers in seven countries across South America: Argentina, Brazil, Chile, Colombia, Ecuador, Uruguay, and Venezuela. Surveys were collected in collaboration with teams from each country. Additional data on soils, climates, and future climate scenarios were collected from various sources. The Ricardian approach was then applied to measure the sensitivity of land value and net revenue per hectare to climate and other factors (Mendelsohn, Nordhaus, and Shaw 1994). 
Separate analyses are made of the land values of the whole sample, irrigated land, and rainfed. Further, one additional analysis was made of net revenue using the whole sample to compare annual net revenues against land values.

The paper is divided into five parts. The next section develops the theory. The third section describes our data and sources. The fourth section of the paper discusses the empirical results from analyzing the cross sectional data across the seven South American countries. The fifth section uses future climate scenarios to predict the impact of climate change. Assuming that long-term intertemporal effects resemble the measured cross sectional effects, we predict the impact of climate change on our sample of farms. Further assuming that climate impacts depend only on climate, we then extrapolate the results to every country in Latin America. The paper concludes with a discussion of policy implications and caveats.

\section{Theory}

The Ricardian model assumes each farmer maximizes net income subject to the exogenous conditions of their farm. Specifically, the farmer chooses the crops, livestock, and inputs that maximize:

$\operatorname{Max} \pi=P_{q_{i}} Q_{i}\left(L_{C}, X, L, K, I R, C, W, S\right)-P_{X} X-P_{L} L-P_{K} K-P_{I R}$

where $\pi$ is net income, $\mathrm{P}_{\mathrm{qi}}$ is the market price of crops and livestock $\mathrm{i}, \mathrm{Q}_{\mathrm{i}}$ is a production function for crops and livestock $\mathrm{i}, \mathrm{X}$ is a vector of annual inputs such as seeds, fertilizer, and pesticides, $\mathrm{L}$ is a vector of labor (hired and household), $\mathrm{K}$ is a vector of capital such 
as tractors and harvesting equipment, $\mathrm{C}$ is a vector of climate variables, IR is a vector of irrigation choices, $\mathrm{W}$ is available water for irrigation, $\mathrm{S}$ is a vector of soil characteristics, $\mathrm{P}_{\mathrm{x}}$ is a vector of prices for the annual inputs, $\mathrm{P}_{\mathrm{L}}$ is a vector of prices for each type of labor, $\mathrm{P}_{\mathrm{K}}$ is the rental price of capital, and $\mathrm{P}_{\mathrm{IR}}$ is the annual cost of each type of irrigation system.

If the farmer chooses the crops and livestock that provide the highest net income and chooses each input in order to maximize net income, the resulting chosen net income will be a function of just variables that are exogenous to the farmer (variables he cannot choose):

$\pi^{*}=f\left(P_{q}, C, W, S, P_{X}, P_{L}, P_{K}, P_{I R}\right)$

In a competitive land market, rents would be equal to the net profit from the land (Ricardo 1817). The present value of these rents would equal land value.

There are consequently two ways to estimate a Ricardian model: one is to use land value as the dependent variable (Mendelsohn, Nordhaus, and Shaw 1994) and the other is to use net revenue per year as the dependent variable (Mendelsohn et al. 2001; Kurukulasuriya et al. 2006; Seo et al. 2005). Both measures of land value are expressed in USD/ha. Land value or net revenue per hectare is regressed on climate, soils, and other economic variables across space. This study is the first to compare land values and net revenue using the same sample. A priori, the land value measure is expected to be a better measure because it reflects the expected value of net revenue. The net revenue measure, in contrast, captures the random features of a single year such as the 
weather that year.

In repeated studies, the land value per hectare of cropland has been found to be sensitive to seasonal precipitation and temperature (Mendelsohn et al. 1994; 2001; Kurukulasuriya et al. 2006). Further, because the response is nonlinear, a quadratic functional form has been used for climate. Our model is then,

$$
\begin{aligned}
V_{i}=a_{0} & +\sum_{k=\text { sum }, \text { win }}\left(b_{k} \cdot T_{k}+c_{k} \cdot T_{k}^{2}+d_{k} \cdot P_{k}+e_{k} \cdot P_{k}^{2}\right) \\
& +\left[a_{0}{ }^{\prime}+\sum_{k=\text { sum, win }}\left(b_{k}{ }^{\prime} \cdot T_{k}+c_{k}{ }^{\prime} \cdot T_{k}^{2}+d_{k}{ }^{\prime} \cdot P_{k}+e_{k}{ }_{k}^{\prime} \cdot P_{k}^{2}\right)\right] * D_{\text {large }} \\
& +\sum_{j} r_{j} \cdot Z_{j}+\varepsilon_{i}
\end{aligned}
$$

where the dependent variable is land value (or net revenue) per hectare, $\mathrm{T}$ and $\mathrm{P}$ represent temperature and precipitation variables, $\mathrm{D}_{\text {large }}$ is a dummy for commercial farms, and $\mathrm{Z}$ represents a set of relevant socio-economic variables. Although previous Ricardian studies in other regions have been able to discern four distinct seasons, the seasonal climate variables in this data set are highly correlated and therefore the seasonal coefficients were found to be insignificant. The model consequently relies on only winter and summer temperature and precipitation.

In Latin America, there is a large difference between small household farm and large commercial establishments. We wish to test whether the climate sensitivity of both types of farms are the same. The model (3) separates small farms from large farms by including climate variables multiplied by the dummy variable for the large farms. 
The change in land value due to a marginal change in temperature for small and large farms is then:

$$
\begin{aligned}
& \frac{\partial V_{i}}{\partial T_{k}}=b_{k}+2 \cdot c_{k} \cdot T_{k} \text { if } \mathrm{D}_{\text {large }}=0 \\
& \frac{\partial V_{i}}{\partial T_{k}}=\left(b_{k}+b_{k}^{\prime}\right)+2 \cdot\left(c_{k}+c_{k}^{\prime}\right) \cdot T_{k} \text { if } \mathrm{D}_{\text {large }}=1
\end{aligned}
$$

Note that the relevant temperature in (4) may be different for small and large farms. For example, if one were interested in the marginal effect at the mean for each farm type, one would use the small farm mean temperature and large farm mean temperature respectively. A similar result holds for precipitation. Annual effects are the sum of the summer and winter effects. That is, we add the same change in temperature or precipitation to each season.

We also explore estimating a separate regression for rainfed and irrigated land (as suggested by Schlenker et al. 2005). Estimating separate regressions for rainfed and irrigated land assumes that the farms of each type are exogenous, independent of climate. In separate papers, we explore whether farmers choose irrigation or rainfed (Kurukulasuriya and Mendelsohn 2006; Mendelsohn and Seo 2006) depending on climate.

The Ricardian model does not readily translate into a model of a single crop. Individual crops have their own net revenue function with respect to climate. The Ricardian function is the locus of all the maximum net revenue choices across the full set 
of crops. Figure 1 depicts a set of such crop specific net income functions with respect to temperature. At cool temperatures, farmers would choose to grow wheat. As temperatures rise, farmers would switch from wheat to corn. As temperatures grow warmer, they might shift from corn to millet which is more heat tolerant. The Ricardian function, (2), captures the locus of maximum profits for each temperature. It reveals the net effect of changing an exogenous variable, in this case, temperature. The assumption across space is that farmers find the outputs and inputs that maximize net income given the climate they face. Cross sectional data can therefore be used to trace out the Ricardian function.

We assume that farmers will continue to maximize profits if climate changed and so remain on the Ricardian function over time as well. The change in welfare, $\Delta \mathrm{V}$, resulting from a climate change from $\mathrm{C}_{0}$ to $\mathrm{C}_{1}$ can then be measured as follows.

$$
\Delta V_{\text {land }}=V_{\text {land }}\left(C_{1}\right)-V_{\text {land }}\left(C_{0}\right)
$$

Whether farmers remain precisely on the Ricardian function each year is not likely as there is a great deal of variance in weather as well as uncertainty about the path of climate change. There could be substantial transition costs over time (Kelly et al. 2005). We argue that the Ricardian model measures long-term impacts after adjustments have been resolved.

Note also that this measure of welfare assumes that prices are constant. With an inelastic demand for food, changes in the world supply of food would change food prices. 
Because the analysis assumes prices do not change, the Ricardian model overestimates the welfare benefits/losses of increases/decreases in global output. Further, it is important to remember that welfare reflects what happens to consumers as well as farmers. Reductions in prices would clearly benefit consumers whereas increases in prices would benefit farmers. However, although it is likely that climate change will have large impacts on local production, it is not as clear what impact climate change will have on global production because some regions will become more productive as others become less so (McCarthy et al. 2001). Consequently, it is not evident how prices will change.

\section{Data}

We collected 2500 surveys from seven countries in Latin America. Argentine, Uruguay, Chile, and Brazil were chosen from the 'Southern cone' region, and Venezuela, Ecuador, and Colombia were chosen from the Andean region. Countries were chosen to cover a wide range of climate zones and given the availability of researchers. The distribution of surveys used by country is displayed in Table 1 .

The districts were sampled to obtain representation of each climate zone within each country. A wide range of climates are therefore present in the sample. Of course, climates that could not support any agriculture were not surveyed. In each country, 1530 districts were selected and 20-30 households were interviewed in each district. Within each district, cluster sampling was done to control the cost of the survey. We treat this sample as though it were a representative sample of farms in Latin America although it is not a truly random sample.

The surveys collected data about farming activities and crop and livestock 
production during the period from July 2003 to June 2004. The surveys also recorded climate and weather related perceptions of the farmers. Data on farm size and land value per hectare were also collected. Land values vary substantially by country as shown in Table 1. The Andean countries (Colombia, Ecuador, and especially Venezuela) have distinctly lower land values. This reflects smaller farms, poorer growing conditions, and more labor intensive farming technologies.

The climate data come from two sources: temperature observations from the US Defense Department Satellite and rainfall observations from World Meteorological Organization. In earlier comparisons across Brazil, it was found that the temperature measures from the satellite were superior to the interpolated weather station measures (Mendelsohn et al 2006a). Most rural areas do not have a weather station nearby and so require interpolation. The satellites make direct observations over the entire land area using microwave imagers. These measures are very effective at capturing temperature but cannot directly capture precipitation. Satellites can measure soil wetness but this index is inferior to the interpolated station measures of precipitation because it is influenced by irrigation, large water bodies, and dense forests (Mendelsohn et al. 2006a).

Soil data were obtained from the FAO digital soil map of the world CD ROM. The data was extrapolated to the district level using Geographical Information System. The data set reports 26 major soil groups, soil texture, and land slope at the district level.

Some variables used in earlier Ricardian studies of the US such as the precise latitude of the farm, water availability, and some soil definitions are not available in this study. However, this study includes detailed data about individual farms, farming activities, and farmers that was not available in the US studies. 


\section{Results}

Our analysis is inclusive of all the crops in the region. The most important crops are cereals (wheat, maize, barley, rice, oats), oil seeds (soybean, peanuts, sunflower), vegetables/tubercles (potatoes, cassava), a variety of perennial grasses, and specialty crops such as cotton, tobacco, tea, coffee, cacao, sugarcane, and sugar beet. Major tree/shrub crops include a large variety of fruits, oil palm, and others. The analysis also includes the value of livestock. Latin American farms rely a great deal on beef cattle and dairy cattle but also chickens, pigs, and sheep.

Although commercial agriculture and agro-industry businesses are well developed in a few countries, there are many places in the continent that still rely on small household farming systems. In rural communities in Central America and the Andean valleys and plateaus for example, small farms are part of subsistence lifestyles with heavy reliance on labor inputs. These small farms may be more sensitive to climate change than large commercial farms (Rosenzweig and Hillel, 1998). We test this hypothesis by examining the climate sensitivity of both small and large farms. Small farms are defined as farms with less than 30 hectares of land.

Two climate regressions are reported in Table 2. Both regressions rely on an unweighted regression of the whole sample of farms ${ }^{2}$. However, the first regression uses land value as the dependent variable and the second regression uses annual net revenue. The geological variables such as elevation, slope, texture, and the various types of soils are significant determinants of net revenue and especially land value. In

\footnotetext{
2 Although Mendelsohn, Nordhaus and Shaw [1994] use weighted regressions, their unit of observation is a county not a farm. There is substantial variation in the number of farms in a county, a problem that does not exist in this study.
} 
the land value regression, many soils are beneficial (Cambisols, Ferralsols, Phaeozems, Luvisils, Arenosols, Vertisols and Yermosols), while Regosols are harmful. In the net revenue regression, fewer soils are significant; Arenosols and Vertisols are beneficial. Both regressions agree that farms have higher value when the texture of the soil is a mix of sand and clay but lower value when the soils are just clay. Both models agree that households with electricity earn more revenue but only the land value regression also valued farms with a computer. Electricity and computers may contribute to productivity or they may simply reflect other relevant factors such as proximity to urban markets. The age of the head of the household has a negative effect but is significant only in the net revenue regression. The gender of the farmer is insignificant. A dummy variable for countries in the Andes region is highly negative in both regressions. The variable may reflect technology or other regional characteristics. For example, the Southern Cone countries have a more intensive trading network that may help support agriculture.

From the regression coefficients on temperature, it appears that net revenues are highly sensitive to especially summer temperature. Large farms have a slightly different response to summer temperature compared to small farms. The negative squared terms reveal that both types of farms have a hill-shaped response to temperature. From the tstatistics of the precipitation coefficients, it is clear that rainfall has a less significant effect on net revenues than temperature. The insignificant coefficients on the large farm precipitation interaction terms imply that small and large farms have similar precipitation responses. The F statistics to test the hypothesis that the set of large farm interaction parameters are zero is 8.4 in the land value regression and 9.5 in the net revenue regression. In both cases, the hypothesis is rejected at $1 \%$ significance level. In other words, small and large farms have different climate sensitivities. 
In Table 3, marginal effects and elasticities are presented for the mean climate in the sample. Both regressions imply that summer warming decreases farm land values for both small and large farms whereas winter warming is predicted to be beneficial (though negative and insignificant for small farms in the net revenue regression). The net effect of a $1^{\circ} \mathrm{C}$ annual warming is to decrease land values by 111 USD for small farms and by 78 USD in large farms. A similar result is found for net revenues. The marginal results confirm the hypothesis that small farms are slightly more vulnerable to warming than large farms. The land value regression implies that summer precipitation is beneficial and winter precipitation is harmful. This confirms earlier research. Precipitation in the summer helps net revenues whereas precipitation in the winter helps pests.

However, the net revenue regression implies that summer and winter precipitation is harmful. A 10 percent increase in annual rainfall would increase the land value of small farms and have no effect on the land value of large farms. In contrast, a ten percent increase in rainfall would reduce the net revenues for both small and large farms. However, the difference in these results between the net revenue and land value regressions is not statistically significant according to the bootstrap analysis.

Figure 2a plots land values against annual temperature for small and large farms. Both types of farms have a hill-shaped response, but the optimum temperature (highest net revenue) is slightly lower in the small farms $\left(14^{\circ} \mathrm{C}\right)$ versus large farms $\left(16^{\circ} \mathrm{C}\right)$. The net revenue response functions are also hill-shaped for small and large farms (Figure 2b). However, with the net revenue response function, the optimum temperature for small farms is even lower $\left(8^{\circ} \mathrm{C}\right)$. The land value results imply that small farms at $14^{\circ} \mathrm{C}$ 
generally have higher net revenues, but in the particular year of the sample, small farms with cooler long run temperatures had higher annual revenue. In practice, the weather during the sample year for farms near the equator was normal but the weather in the more southern hemisphere was cooler than normal. This difference can explain some of this variation between the land value and net revenue results.

Figure 3a shows the response of land value to rainfall for small and large farms and Figure $3 \mathrm{~b}$ shows the net revenue response. The small and large farm responses to precipitation are similar. Land values tend to increase with more annual precipitation but net revenues decrease with precipitation for both small and large farms.

We also conduct a Ricardian analysis on subsamples of rainfed farms and irrigated farms following Schlenker et al 2005. Table 4 shows the results of these two regressions on land value. There is no question that the rainfed and irrigated models are different. They respond differently to many soil types, altitude, mixed soil texture, electricity, computers, and the age of the head of household. Although some of the differences are hard to explain, generally irrigation is more sensitive than rainfed to other factors that affect net revenue. The high cost of installing irrigation is profitable only if the farm is otherwise highly productive. The dummy variable for the Andes region is highly negative for rainfed but zero for irrigated land implying the problems with farms in the Andes region applies strictly to rainfed farmers.

However, the key comparison in Table 4 concerns climate. Both the rainfed and irrigated farm models have many significant temperature coefficients but few significant precipitation coefficients. The individual interaction terms between climate and large farms suggests that large and small farms of each type have similar climate response 
functions. However, the set of large farm interaction parameters are significant. The hypothesis that the set of large farm interaction parameters is zero is rejected at $1 \%$ significance level according to the $\mathrm{F}$ test statistics of 6.3 in the rainfed regression and 5.5 in the irrigated land regression. In other words, large and small farms have significantly different climate coefficients.

In order to test this more formally, we compute the marginal impacts of climate in Table 5. The marginal temperature effects of rainfed and irrigated lands are quite different. Rainfed farms are very sensitive to summer temperatures. Small farms have a negative temperature elasticity of -2.8 and large farms of -1.7 . Small irrigated farms have no response to summer temperature and large irrigated farms actually benefit from warmer summer temperatures. Warmer winter temperatures benefit small rainfed farms whereas warmer winter temperatures are harmful to both small and large irrigated farms. The results for summer precipitation are more consistent across farm types although large irrigated farms have surprisingly high elasticities. The results for winter precipitation follow a mixed pattern being harmful to large rainfed farms and small irrigated farms but beneficial to large irrigated farms. The positive effect of an increase in winter precipitation on small rainfed farms and the positive effect of an increase in winter temperature on large rainfed farms are not significant. Most of the marginal climate effects for irrigated farms are not significant. However, an F test of whether rainfed and irrigated farms have the same climate response coefficients is rejected at the $1 \%$ level $(\mathrm{F}=9.16)$ for small farms and at the $5 \%$ level $(\mathrm{F}=2.25)$ for large farms.

\section{Climate Scenarios}

In order to predict climate change impacts for the coming century, we examine climate 
change scenarios predicted by Atmospheric-Oceanic Global Circulation Models (AOGCM's). We rely on a broad set of scenarios that predict a wide range of outcomes, consistent with the expectations in the most recent IPCC report (Houghton et al. 2001). Specifically, we use the A1 scenarios from the following models: CCC (Boer et al. 2000), CCSR (Emori et al. 1999), and PCM (Washington et al. 2000). In each case, a countryspecific forecast is generated by weighting each model grid zone by its population.

Table 6 summarizes the climate scenarios of the three climate models. The Latin American mean temperature and rainfall predicted for the year 2020, 2060, and 2100 are presented. The models provide a range of predictions: PCM predicts a $1.9^{\circ} \mathrm{C}$ increase, CCSR predicts a $3.3^{\circ} \mathrm{C}$ increase, and CCC predicts a $5^{\circ} \mathrm{C}$ increase in average temperature in 2100. The temperature projections of all the models steadily increase over time. The models also provide a range of rainfall predictions. PCM predicts a general increase in rainfall, whereas CCSR and CCC predict a reduction by 2100 . The rainfall predictions of the models do not steadily increase but rather have a noisy pattern over time. The climate change predictions, however, are country-specific. For example, even though the mean rainfall for Latin America might increase (decrease), some countries will nonetheless experience a reduction (increase) in rainfall.

For each climate scenario and each time period, we add the climate model's predicted change to the baseline temperature in each district. We then multiply the climate models predicted percentage increase in precipitation times the baseline precipitation in each district or province. This gives us a new climate for every district in Latin America. We then compute the land value per hectare (or net revenue) of the current climate and each new climate. Subtracting the future land value (net revenue) 
estimate from current land value yields a change in land value per hectare in each location. We also examine the percentage change in the value of land (net revenue) per hectare.

Table 7 shows the results for small farms in the sample. With the Ricardian model of the entire sample, all three climate scenarios predict that warming will be harmful to small farms and that the damage will increase over time as temperatures rise. According to the CCC scenario, by 2100 , small farms will lose $61 \%$ of their land value. The CCSR predicts that by 2100 , small farms will have lost $36 \%$ of their land value. PCM predicts small farms will lose only $13 \%$ of their income by 2100 . These different predictions are largely due to the difference in predicted temperature change across the three models. The net revenue results for the full sample are almost identical to the land value results. Both sets of regressions in Table 2 make very similar predictions about future climate change impacts. All the Ricardian results using the entire sample are significant except for the 2020 PCM prediction.

The Ricardian model results for small rainfed farms are quite similar to the small farm results using the entire sample. The severe climate scenarios generate similar large losses (compare the first, second and third columns for CCC and CCSR in Table 7). However, the results for PCM are different. The rainfed model suggests the PCM scenario is highly beneficial at first with the benefits eroding over time as temperatures rise. The response for irrigated farms is far more muted. The CCC and CCSR scenarios are predicted to be harmful but much less so. With the PCM model, the net revenues of small irrigated farms are consistently expected to be higher for the entire century. These results within the subsamples give an impression of how climate will 
affect each land type. However, they are probably less reliable as a description of the total welfare impact because they assume that farmers have no choice about farm types. It is likely that farmers will switch farm types as climate changes (Mendelsohn and Seo 2006).

Table 8 shows the results for large farms in the sample. The land value results for the full Ricardian regression and all the climate scenarios are almost identical with the results for small farms. The severe climate scenario will result in substantial losses of net revenue whereas the more modest scenario leads to smaller losses. The results from the full Ricardian model suggest that small and large farms have identical climate sensitivities. In contrast, the large farm results in Table 8 from the rainfed and irrigated samples are different from the small farm outcomes in Table 7. The rainfed results suggest that big farms are a little more sensitive to climate change than small farms. They suffer slightly larger damages in each scenario. However, large irrigated farms generally benefit from warming. In fact, the larger and more severe the warming, the larger are the benefits.

Our final analysis extrapolates the results to all countries in Latin America. The analysis assumes that climate impacts are dependent only on the climate in each location. The purpose of this analysis is to present the likely distribution of climate effects across districts. Using the full Ricardian model, we predict the change in land value per hectare by 2100 for each district in Latin America using the PCM, CCSR, and CCC scenarios for small and large farms. Figure $4 \mathrm{a}$ describes the PCM results for small farms across Latin America. The PCM scenario is generally predicted to be beneficial for small farms but the scenario will not have the same impact on each district. The 
impacts will depend on initial climates. Small farms in the currently cooler regions of Argentina and Chile and high mountains of Bolivia will gain more than average. Small farms in the relatively hot regions of Venezuela, Colombia, and northern South America and Central America will see losses.

A completely different picture emerges in Figure $4 \mathrm{~b}$ with the $2100 \mathrm{CCC}$ scenario for small farms. The CCC scenario is generally harmful to small farms. This is especially evident in the Amazon and the rest of Brazil but it even extends to Paraguay and northern Argentina. Farms in a few regions benefit in southern Argentina, Chile, the Pacific coast, and northern Mexico, but the scenario is generally grim for small farms in Latin America. The overall magnitude of the damage from the CCSR 2100 scenario in Figure $4 \mathrm{c}$ falls between the results for the PCM and CCC scenarios. However, distribution of impacts across space is similar to the results from the CCC 2100 scenario.

In Figure 5a, we see the results of the 2100 PCM scenario for large farms. Large farms benefit from the PCM scenario in all but a few places in northern South America where there are small losses. Farms in Argentina, Chile, Paraguay and Mexico especially benefit from the slight increase in temperature and large increase in precipitation.

In Figure 5b, we see the results of the $2100 \mathrm{CCC}$ scenario for large farms. The CCC scenario is harmful to large farms in general but there is a lot of variation in the impacts across the landscape. Large farms in Bolivia and Paraguay are especially hard hit by the CCC scenario. Damages are also high for the Amazon basin and northern Argentina. However, large farms in Mexico, Peru, southern Chile, and southern Argentina all benefit from this scenario. The distribution of impacts with the CCSR scenario in 
Figure $5 \mathrm{c}$ is similar to the results from the $\mathrm{CCC}$ scenario in Figure $5 \mathrm{~b}$ but there are slightly higher damages in the Amazon basin, Ecuador, and Peru.

\section{Conclusion}

We examine the vulnerability of Latin American agricultural production to climate change. Surveys were collected across 7 countries in South America. Four countries are from the Southern Cone region and three countries are from the Andean region. Using cross sectional analyses, we test the effect of climate, soils, and other control variables on both land value and net revenue.

Our results indicate that many of the control variables explain the geographic variation in land value and net revenues across Latin American farms. Many soils are relatively beneficial to farms, whereas a few soils are harmful. Soils with some mix of sand and clay command relatively higher profits whereas clay soils are relatively harmful. Farms with electricity earn significantly higher profits and farms with computers have higher land values.

However, the main focus of this study concerns the sensitivity of farm values to climate. Both land value and net revenue are sensitive to temperature and precipitation. The land values and net revenues of farms have a hill-shaped relationship with temperature. Farms at moderate (temperate) temperatures earn more profits compared to farms at extreme (tropical) temperatures. Small farms and large farms have very similar responses to temperature and summer precipitation. However, small and large farms did have different responses to winter precipitation. Large farms located in places with higher winter precipitation had lower land values but winter precipitation had no effect on the land value of small farms. Rainfed farms and irrigated farms have 
different responses to climate. The elasticity of land value to summer temperature was 2.8 for small and -1.7 large rainfed farms but the elasticity for irrigated farms was zero for small farms and +0.9 for large farms. Further, large rainfed farms have higher values in places with more precipitation but large irrigated farms have higher values in dryer places.

Using the cross sectional results, we also predicted how future AOGCM scenarios would change land values and net revenues. Three climate models, CCC, CCSR, and PCM, were used to predict a range of climate outcomes. Looking at just results within the sample, the CCC scenario predicts the largest damage, the PCM scenario predicts the smallest damage, and the CCSR scenario predicts a moderate damage in between. For both small and large farms, CCC predicts a gradual increase in damage from about $16 \%$ in 2020 , to $33 \%$ in 2060 , to $61 \%$ in 2100 . In contrast, the CCSR model predicts damages of about half that size and the PCM model about one fourth as large. Another interesting result from the climate simulations is that small and large farms have very similar final impacts. The hypothesis that the impacts to small farms would be much larger than the impacts to large farms was not supported by the results.

We also compared using net revenues instead of land values as the dependent variable of the Ricardian regression, the measure of farm profitability. The results from the net revenue analysis were quite similar although not identical to the land value analysis. Temperature has a hill-shaped relationship with net revenue as it does with land value. However, precipitation is predicted to be strictly harmful to net revenue. In contrast, farms with more summer precipitation had higher land values. However, the predicted impacts of the climate scenarios, suggested the net revenue impacts were 
very similar to the land value results. The CCC scenario generates large damages and the PCM scenario much smaller damages.

Looking across Latin America, the climate change impacts to each farm are predicted to vary across the landscape. Places that are currently cool generally will benefit from warming. However places that are currently hot will generally be damaged by warming. Further, each climate scenario has its own prediction of how climate will change in each country. These country-specific predictions also have a very large effect on the distribution of impacts over the landscape.

For policy makers, the results of this analysis reveal that Latin American agriculture is vulnerable to climate change. If global warming is mild, the impact will be small. However, if severe scenarios come to pass, farmers could lose up to $62 \%$ of their net revenue. This would be a stunning blow to the agricultural sector in Latin America. The impact would be even more devastating to the most vulnerable regions in Latin America. Countries and international agencies may want to direct resources at providing relief and new opportunities for the rural poor who are likely to be the most affected by climate change. They may also want to facilitate the migration of people from the parts of the countryside most damaged by warming to more urban settings as part of a general development strategy.

There are a number of caveats that readers should keep in mind when interpreting these results. First, the cross sectional analysis is vulnerable to omitted variables. If important variables have been left out of the analysis and they are correlated with climate, they can bias the results. Second, the analysis did not consider carbon fertilization which is predicted to increase future crop productivity (Reilly et al 1996). Third, the 
analysis did not include changes in prices. If some of the more severe scenarios come to pass, there may be changes in wages, other inputs, and output prices. These price changes will moderate the welfare impacts. Fourth, the analysis did not take into account future technological change. In general, technical change is expected to increase overall crop and livestock productivity. However, technical change could be directed specifically to deal with higher temperatures or dryer conditions. For example, Brazil has developed a new soybean variety to grow in the hot and dry conditions of the Mato-Grosso region. Such climate specific technological changes would increase the potential benefits and reduce the damages from climate change. 


\section{References}

Boer, G., G. Flato, and D. Ramsden (2000), “A transient climate change simulation with greenhouse gas and aerosol forcing: projected climate for the $21^{\text {st }}$ century", Climate Dynamics 16, 427-450.

Dinar, A., R. Mendelsohn, R. Evenson, J. Parikh, A. Sanghi, K. Kumar, J. McKinsey, S. Lonergan (eds.), 1998, Measuring the Impact of Climate Change on Indian Agriculture, World Bank Technical Paper No. 402, Washington, D.C.

Emori, S. T. Nozawa, A. Abe-Ouchi, A. Namaguti, and M. Kimoto (1999), “Coupled Ocean-Atmospheric Model Experiments of Future Climate Change with an Explicit Representation of Sulfate Aerosol Scattering”, J. Meteorological Society Japan 77: 1299-1307.

Houghton, J., Y. Ding, D. Griggs, M. Noguer, P. Van der Linden, X. Dai, K. Maskell, and C. Johnson (eds.) 2001, Climate Change 2001: The Scientific Basil, Intergovernmental Panel on Climate Change, Cambridge University Press: Cambridge.

Kelly, D.L., C.D. Kolstad, and G. T. Mitchell. 2005. "Adjustment Costs from Environmental Change.” Journal of Environmental Economics and Management 50 (3): 468-95.

McCarthy, J., O. Canziani, N. Leary, D. Dokken, and K. White (eds.) 2001, Climate Change 2001: Impacts, Adaptation, and Vulnerability, Intergovernmental Panel on Climate Change Cambridge University Press: Cambridge.

Mendelsohn, R., W. Nordhaus and D. Shaw, "The Impact of Global Warming on 
Agriculture: A Ricardian Analysis", American Economic Review 84(1994): 753771.

Mendelsohn, R., W. Nordhaus, and D. Shaw, "Climate Impacts on Aggregate Farm Values: Accounting for Adaptation" Agriculture and Forest Meteorology 80(1996): 55-67.

Mendelsohn, R. and W. Nordhaus, "The Impact of Global Warming on Agriculture: Reply to Cline" American Economic Review 86(1996): 1312-1315.

Mendelsohn, R., W. Nordhaus, and D. Shaw, (1999), “The Impact of Climate Variation on US Agriculture” In Mendelsohn, R. and Neumann, J. (eds), The Economic Impact of Climate Change on the Economy of the United States, Cambridge University Press, Cambridge, UK.

Mendelsohn, R. and A. Dinar, "Climate Change Impacts on Developing Country Agriculture" World Bank Research Observer 14(1999): 277-293.

Mendelsohn, R.(Ed), 2001, Global Warming and the American Economy: A Regional Analysis, Edward Elgar Publishing, UK.

Mendelsohn, R., A. Dinar and A. Sanghi, "The Effect of Development on the Climate Sensitivity of Agriculture", Environment and Development Economics 6(2001): 85-101.

Mendelsohn, R., A. Basist, F. Kogan, and P. Kurukulasuriya. (2006a), “Climate Analysis with Satellite Versus Weather Station Data" Climatic Change (forthcoming).

Mendelsohn, R., A. Basist, P. Kurukulasuriya, and A. Dinar. (2006b) "Climate and Rural Income", Climatic Change (forthcoming). 
Mendelsohn, R. and N. Seo. (2006) “An Integrated Farm Model of Crops and Livestock: Modeling Latin American Agricultural Impacts and Adaptation to Climate Change" Draft.

Ricardo, D. (1817), "On the Principles of Political Economy and Taxation”, John Murray, London.

Schenkler, W., Hanemann, M., and Fisher, A.: 2005. "Will US Agriculture Really Benefit From Global Warming? Accounting for Irrigation in the Hedonic Approach" American Economic Review 95: 395-406

Seo, Niggol S., R. Mendelsohn, and M. Munasinghe, (2005), "Climate Change and Agriculture in Sri Lanka: A Ricardian Valuation”, Environment and Development Economics 10: 581-596.

Washington, W., et al., "Parallel Climate Model (PCM): Control and Transient Scenarios". Climate Dynamics 16(2000): 755-774.

World Development Indicators. 2004. World Bank. Washington D.C. http://devdata.worldbank.org

World Resources. 2005. World Resources Institute. Washington D.C. 
Table 1: National Means of the Variables.

$\begin{array}{lrrrrrrr}\text { Var. } & \text { Argentine } & \text { Brazil } & \text { Chile } & \text { Colombia } & \text { Ecuador } & \text { Uruguay } & \text { Venezuela } \\ \text { Temperature } & 14.4 & 20.2 & 9.3 & 16.8 & 14.8 & 15.2 & 21.8 \\ \text { Precipitation } & 72.1 & 122.6 & 77.8 & 162.9 & 99.6 & 101.4 & 83.8 \\ \text { Land Val/Ha } & 1818 & 2606 & 962 & 65 & 2280 & 1018 & 3 \\ \text { Size }(\mathrm{Ha}) & 122.8 & 176.6 & 39.9 & 61.8 & 84.0 & 50.3 & 111.8 \\ \mathrm{~N} & 395 & 639 & 369 & 341 & 174 & 119 & 226\end{array}$


Table 2: Ricardian Regressions Using Whole Sample

\begin{tabular}{|c|c|c|c|c|}
\hline \multirow[b]{2}{*}{ Variable } & \multicolumn{2}{|c|}{ Land Value } & \multicolumn{2}{|c|}{ Net Revenue } \\
\hline & Coef. & T-stat. & Coef. & T-stat \\
\hline Intercept & -2409 & -3.66 & -64.21 & -0.23 \\
\hline Temperature summer & 476 & 5.87 & 140 & 4.01 \\
\hline Temperature summer squared & -17.0 & -6.95 & -4.81 & -4.53 \\
\hline Temperature winter & 166 & 3.46 & -18 & -0.82 \\
\hline Temp winter squared & -4.46 & -2.89 & 0.42 & 0.59 \\
\hline Precipitation Summer & 2.97 & 1.58 & -0.66 & -0.84 \\
\hline Precipitation Summer Squared & 0.00 & -0.46 & 0.00 & 1.10 \\
\hline Precipitation Winter & -3.14 & -1.56 & -1.80 & -2.29 \\
\hline Precipitation Winter Squared & 0.00 & 0.26 & 0.00 & 0.09 \\
\hline Temp summer*Large Farms & -171 & -2.52 & -87 & -2.96 \\
\hline Temp summer Sq*Large Farms & 6.73 & 2.83 & 2.16 & 2.13 \\
\hline Temp winter*Large Farms & 45.5 & 0.59 & 56.4 & 1.67 \\
\hline Temp Winter Sq*Large Farms & -2.26 & -0.88 & -1.00 & -0.88 \\
\hline Prec summer*Large Farms & 0.33 & 0.11 & -1.24 & -0.86 \\
\hline Prec summer Sq*Large Farms & 0.00 & -0.19 & 0.00 & 0.52 \\
\hline Prec winter*Large Farms & -1.40 & -0.41 & 1.77 & 1.31 \\
\hline Prec winter sq*Large Farms & 0.00 & -0.03 & 0.00 & -0.58 \\
\hline Soil Cambisols & 5.92 & 1.64 & 1.62 & 1.18 \\
\hline Soil Ferrasols & 10.96 & 4.51 & 0.80 & 0.87 \\
\hline Soil Phaeozems & 5.98 & 2.50 & 1.16 & 1.24 \\
\hline Soil Luvisols & 9.88 & 3.27 & 0.19 & 0.18 \\
\hline Soil Arenolsols & 18.58 & 3.59 & 7.10 & 3.35 \\
\hline Soil Regosols & -11.55 & -3.71 & -0.54 & -0.33 \\
\hline Soil Vertisols & 13.82 & 4.86 & 5.01 & 4.36 \\
\hline Soil Yermosols & 35.48 & 4.21 & 0.92 & 0.31 \\
\hline Altitude & -0.19 & -1.85 & -0.06 & -1.38 \\
\hline Electricity dummy & 832 & 5.60 & 129 & 2.10 \\
\hline Computer dummy & 397 & 3.59 & 49 & 1.07 \\
\hline Texture(Mixed) & 706 & 5.23 & 232 & 4.30 \\
\hline Texture(Clay) & -1134 & -6.75 & -258 & -3.89 \\
\hline Age of the head & -4.12 & -1.50 & -2.00 & -2.03 \\
\hline Female dummy & -197 & -1.20 & -26 & -0.40 \\
\hline
\end{tabular}




\begin{tabular}{|c|c|c|c|}
\hline Andes dummy & -1749 & -11.39 & -390 \\
\hline $\mathrm{N}$ & 2263 & & 1378 \\
\hline R-sq & 0.24 & & 0.14 \\
\hline \multicolumn{4}{|c|}{ F-test for Large Farm } \\
\hline Interaction Terms & $8.42 * *$ & & $9.54 * *$ \\
\hline
\end{tabular}


Table 3: Land Value and Net Revenue Marginal Effects and Elasticities.

$\begin{array}{lcccc}\text { Land Value } & \begin{array}{l}\text { Summer } \\ \text { Temperature }\end{array} & \begin{array}{l}\text { Summer } \\ \text { Precipitation }\end{array} & \begin{array}{l}\text { Winter } \\ \text { Temperature }\end{array} & \begin{array}{l}\text { Winter } \\ \text { Precipitation }\end{array} \\ \text { Small Farms } & & & & \\ \text { Marginal } & -158.33^{\star \star} & 2.47^{\star \star} & 46.84^{\star \star} & -2.83^{\star \star} \\ \text { Effects } & -1.88^{\star \star} & 0.19^{\star \star} & 0.40^{\star \star} & -0.14^{\star \star} \\ \text { Elasticities } & & & & \\ \text { Large Farms } & & & & \\ \text { Marginal } & -93.34^{\star *} & 2.29^{\star \star} & 14.53 & -4.28^{\star \star} \\ \text { Effects } & -1.49^{\star \star} & 0.27^{\star \star} & 0.18 & -0.27^{\star \star} \\ \text { Elasticities } & & & & \end{array}$

Net Revenue

Small Farms

Marginal

Effects

$-33.44^{\star \star}$

$-0.17$

$-6.22$

$-1.76^{\star \star}$

Elasticities

$-1.59^{\star \star}$

$-0.06$

$-0.22$

$-0.37^{\star \star}$

Large Farms

Marginal

Effects

-51.90 **

$-0.68^{*}$

$-0.45$

Elasticities

$-7.57^{* \star}$

$-0.81^{*}$

$-0.21$

Calculated from results in Table 2.

** denotes a significance at $99 \%$ confidence level and * denotes a significance at $95 \%$ confidence level. 
Table 4: Regressions of the Land Value of Irrigated and Rainfed Farms

\begin{tabular}{|c|c|c|c|c|}
\hline & Rainfed & & Irrigated & \\
\hline Variable & Coef. & T-stat. & Coef. & T-stat \\
\hline Intercept & -3406 & -4.43 & 2083 & 1.34 \\
\hline Temperature summer & 344 & 3.62 & 235 & 1.40 \\
\hline Temperature summer squared & -13.8 & -4.94 & -6.69 & -1.24 \\
\hline Temperature winter & 353 & 6.82 & -317 & -2.17 \\
\hline Temp winter squared & -9.17 & -5.63 & 6.64 & 1.42 \\
\hline Precipitation Summer & 7.53 & 3.54 & 8.77 & 1.28 \\
\hline Precipitation Summer Squared & -0.01 & -2.33 & -0.01 & -0.51 \\
\hline Precipitation Winter & 0.06 & 0.03 & -13.63 & -1.90 \\
\hline Precipitation Winter Squared & 0.01 & 0.69 & 0.06 & 1.81 \\
\hline Temp summer*Large Farms & 105 & 1.48 & -531 & -2.03 \\
\hline Temp summer Sq*Large Farms & -0.56 & -0.23 & 15.47 & 1.72 \\
\hline Temp winter*Large Farms & -144.7 & -1.86 & 27.2 & 0.08 \\
\hline Temp Winter Sq*Large Farms & 2.26 & 0.88 & 2.02 & 0.17 \\
\hline Prec summer*Large Farms & -3.75 & -1.13 & 30.49 & 1.85 \\
\hline Prec summer Sq*Large Farms & 0.01 & 1.01 & -0.12 & -1.99 \\
\hline Prec winter*Large Farms & -5.02 & -1.48 & 26.14 & 1.59 \\
\hline Prec winter sq*Large Farms & 0.00 & -0.34 & -0.11 & -1.56 \\
\hline Soil Cambisols & 5.15 & 1.42 & -0.89 & -0.08 \\
\hline Soil Ferrasols & 10.01 & 4.03 & 22.64 & 3.45 \\
\hline Soil Phaeozems & 2.12 & 0.88 & 26.73 & 3.74 \\
\hline Soil Luvisols & 14.63 & 4.74 & -12.53 & -1.40 \\
\hline Soil Arenolsols & 16.59 & 3.27 & 17.49 & 1.05 \\
\hline Soil Regosols & -8.04 & -2.57 & -8.77 & -0.96 \\
\hline Soil Vertisols & 20.54 & 5.03 & 9.42 & 2.13 \\
\hline Soil Yermosols & 19.20 & 0.63 & 26.28 & 2.42 \\
\hline Altitude & -0.09 & -0.79 & -0.51 & -2.15 \\
\hline Electricity dummy & 585.4 & 4.03 & 1337.1 & 2.54 \\
\hline Computer dummy & 445.1 & 3.78 & 105.8 & 0.43 \\
\hline Texture(Mixed) & 534.1 & 4.00 & 1997.4 & 4.57 \\
\hline Texture(Clay) & -1089 & -6.55 & -961.8 & -1.83 \\
\hline Age of the head & -0.26 & -0.10 & -23.01 & -2.75 \\
\hline Female dummy & -272.5 & -1.62 & 292.7 & 0.70 \\
\hline
\end{tabular}




\begin{tabular}{|c|c|c|c|}
\hline Andes dummy & -1756 & -10.90 & -130 \\
\hline $\mathrm{N}$ & 1753 & & 510 \\
\hline R-SQ & 0.28 & & 0.26 \\
\hline \multicolumn{4}{|c|}{ F-test for Large Farm } \\
\hline Interaction Terms & $6.38 * *$ & & $5.57 * *$ \\
\hline
\end{tabular}


Table 5: Rainfed and Irrigated Farm Marginal Effects and Elasticities.

\begin{tabular}{lrrrr} 
Rainfed & \multicolumn{1}{l}{$\begin{array}{l}\text { Summer } \\
\text { Temperature }\end{array}$} & \multicolumn{1}{l}{$\begin{array}{l}\text { Summer } \\
\text { Precipitation }\end{array}$} & \multicolumn{1}{l}{$\begin{array}{l}\text { Tinter } \\
\text { Temperature }\end{array}$} & \multicolumn{1}{l}{$\begin{array}{l}\text { Winter } \\
\text { Precipitation }\end{array}$} \\
Small Farms & & & & \\
Marginal & & & & \\
Effects & $-184.93^{\star \star}$ & $4.33^{\star \star}$ & $90.63^{\star \star}$ & 1.02 \\
Elasticities & $-2.80^{\star \star}$ & $0.46^{\star \star}$ & $1.02^{\star \star}$ & 0.06 \\
Large Farms & & & & \\
Marginal & & & & \\
Effects & $-110.22^{\star \star}$ & $2.61^{\star \star}$ & 3.96 & $-4.78^{\star \star}$ \\
Elasticities & $-1.68^{\star \star}$ & $0.30^{\star \star}$ & 0.05 & $-0.29^{\star \star}$
\end{tabular}

\section{Irrigated}

Small Farms

Marginal

Effects

3.87

7.37

$-170.17^{*}$

$-5.51$

Elasticities

0.03

0.24

$-0.80^{*}$

$-0.15$

Large Farms

Marginal

Effects

34.49

14.88

$-51.39$

4.73

Elasticities

0.85

1.83

$-0.93$

0.46

Calculated from results in Table 4.

** denotes a significance at $99 \%$ confidence level and * denotes a significance at $95 \%$ confidence level. 
Table 6: AOGCM Climate Scenarios.

\begin{tabular}{|l|c|l|l|l|}
\hline & NOW & 2020 & 2060 & 2100 \\
\hline Temp Summer & ${ }^{\circ} \mathrm{C}$ & & & \\
\hline CCC & 19.9 & $21.4(+1.5)$ & $22.7(+2.8)$ & $24.9(+5.0)$ \\
\hline CCSR & 19.9 & $21.1(+1.2)$ & $22.0(+2.1)$ & $23.0(+3.1)$ \\
\hline PCM & 19.9 & $19.8(-0.1)$ & $20.6(0.7)$ & $21.3(+1.4)$ \\
\hline Temp Winter & ${ }^{\circ} \mathrm{C}$ & & & \\
\hline CCC & 16.4 & $17.7(+1.3)$ & $19.0(+2.6)$ & $21.6(+5.2)$ \\
\hline CCSR & 16.4 & $17.8(+1.4)$ & $18.7(+2.3)$ & $19.6(+3.2)$ \\
\hline PCM & 16.4 & $17.6(+1.2)$ & $18.3(+1.9)$ & $19.0(+2.6)$ \\
\hline Prec Summer & $\mathrm{mm} / \mathrm{mo}$ & & & \\
\hline CCC & 162 & $158(-2.5 \%)$ & $143(-11.7 \%)$ & $142(-12.3 \%)$ \\
\hline CCSR & 162 & $165(+1.9 \%)$ & $166(+2.5 \%)$ & $158(-2.5 \%)$ \\
\hline PCM & 162 & $157(-3.1 \%)$ & $166(+2.5 \%)$ & $165(+1.9 \%)$ \\
\hline Prec Winter & $\mathrm{mm} / \mathrm{mo}$ & & & \\
\hline CCC & 75 & $73(-2.7 \%)$ & $71(-5.3 \%)$ & $76(+1.3 \%)$ \\
\hline CCSR & 75 & $76(+1.3 \%$ & $72(-4.0 \%)$ & $70(-6.7 \%)$ \\
\hline PCM & 75 & $99(+32.0 \%)$ & $99(+32.0 \%)$ & $92(+22.7 \%)$ \\
\hline
\end{tabular}


Table 7: Climate Change Impacts from AOGCM Scenarios to Small Farms.

\begin{tabular}{|c|c|c|c|c|}
\hline & $\begin{array}{c}\text { Land Value: } \\
\text { All }\end{array}$ & $\begin{array}{l}\text { Net Revenue: } \\
\text { All } \\
\text { Small Fa }\end{array}$ & $\begin{array}{l}\text { Land Value: } \\
\text { Rainfed } \\
\text { ns }\end{array}$ & $\begin{array}{c}\text { Land Value: } \\
\text { Irrigated }\end{array}$ \\
\hline $\begin{array}{c}\text { Baseline } \\
2020\end{array}$ & 1728 & 449.3 & 1748 & 1807 \\
\hline $\mathrm{CCC}$ & $-272^{\star \star}(-16 \%)$ & $-81^{\star \star}(-18 \%)$ & $-239 * \star(-14 \%)$ & $-235^{\star \star}(-13 \%)$ \\
\hline CCSR & $-223^{\star \star}(-13 \%)$ & $-68^{\star \star}(-15 \%)$ & $-189 * \star(-11 \%)$ & $-121(-7 \%)$ \\
\hline $\begin{array}{l}\text { PCM } \\
2060\end{array}$ & $13(+1 \%)$ & $-30 * \star(-7 \%)$ & $230 * *(+13 \%)$ & $1007^{\star \star}(+56 \%)$ \\
\hline $\mathrm{CCC}$ & $-570 * \star(-33 \%)$ & $-160 * \star(-38 \%)$ & $-529 * \star(-30 \%)$ & $-519 * *(-29 \%)$ \\
\hline CCSR & $-387^{\star \star}(-22 \%)$ & $-108^{\star \star}(-24 \%)$ & $-368^{\star \star}(-21 \%)$ & $-172(-10 \%)$ \\
\hline $\begin{array}{l}\text { PCM } \\
2100\end{array}$ & $-121^{* \star}(-7 \%)$ & $-69^{\star \star}(-15 \%)$ & $98 *(+6 \%)$ & $944^{\star \star}(+52 \%)$ \\
\hline $\mathrm{CCC}$ & $-1060 * \star(-61 \%)$ & $-288^{\star \star}(-64 \%)$ & $-1004^{\star \star}(-57 \%)$ & $-702(-39 \%)$ \\
\hline CCSR & $-617^{\star \star}(-36 \%)$ & $-170 * *(-38 \%)$ & $-590 * \star(-34 \%)$ & $-438 *(-24 \%)$ \\
\hline PCM & $-228^{\star \star}(-13 \%)$ & $-91^{\star \star}(-20 \%)$ & $-5(0 \%)$ & $1082^{\star \star}(+60 \%)$ \\
\hline
\end{tabular}

Impacts to small farms in the sample measured in USD/ha. .

* implies a significance at $95 \%$ confidence level and ** at $99 \%$ confidence level. 
Table 8: Climate Change Impacts from AOGCM Scenarios to Large Farms.

\begin{tabular}{|c|c|c|c|c|}
\hline & $\begin{array}{c}\text { Land Value: } \\
\text { All }\end{array}$ & $\begin{array}{l}\text { Net Revenue: } \\
\text { All } \\
\text { Large Farm }\end{array}$ & $\begin{array}{c}\text { Land Value: } \\
\text { Rainfed }\end{array}$ & $\begin{array}{c}\text { Land Value: } \\
\text { Irrigated }\end{array}$ \\
\hline $\begin{array}{c}\text { Baseline } \\
2020\end{array}$ & 1135 & 200 & 1284 & 777 \\
\hline $\mathrm{CCC}$ & $-173^{\star \star}(-15 \%)$ & $-127^{\star \star}(-64 \%)$ & $-208^{\star *}(-16 \%)$ & $116(+15 \%)$ \\
\hline CCSR & $-154^{\star \star}(-14 \%)$ & $-84^{\star \star}(-42 \%)$ & $-184^{\star \star}(-14 \%)$ & $119(+15 \%)$ \\
\hline $\begin{array}{l}\text { PCM } \\
2060\end{array}$ & $-61(-5 \%)$ & $-32(-16 \%)$ & $-74(-6 \%)$ & $-23(-3 \%)$ \\
\hline $\mathrm{CCC}$ & $-373^{\star *}(-33 \%$ & $-49(-24 \%)$ & $-449^{\star \star}(-35 \%)$ & $323(+42 \%)$ \\
\hline CCSR & $-248^{\star \star}(-22 \%)$ & $-39(-20 \%)$ & $-300^{\star \star}(-23 \%)$ & $231(+30 \%)$ \\
\hline $\begin{array}{l}\text { PCM } \\
2100\end{array}$ & $-138^{\star}(-12 \%)$ & $13(-6 \%)$ & $-165^{\star \star}(-13 \%)$ & $10(+1 \%)$ \\
\hline $\mathrm{CCC}$ & $-702^{\star *}(-62 \%)$ & $-83(-42 \%)$ & $-837^{\star \star}(-65 \%)$ & $811(+104 \%)$ \\
\hline CCSR & $-397^{\star \star}(-35 \%)$ & $-58(-28 \%)$ & $-483^{\star \star}(-38 \%)$ & $394(+51 \%)$ \\
\hline PCM & $-191^{\star \star}(-17 \%)$ & $-17(-8 \%)$ & $-228^{\star \star}(-18 \%)$ & $35(+5 \%)$ \\
\hline
\end{tabular}

Impacts to large farms in sample measured in USD/ha.

* implies a significance at $95 \%$ confidence level and ** at $99 \%$ confidence level. 
Figure 1: Ricardian Model of Net Income and Temperature

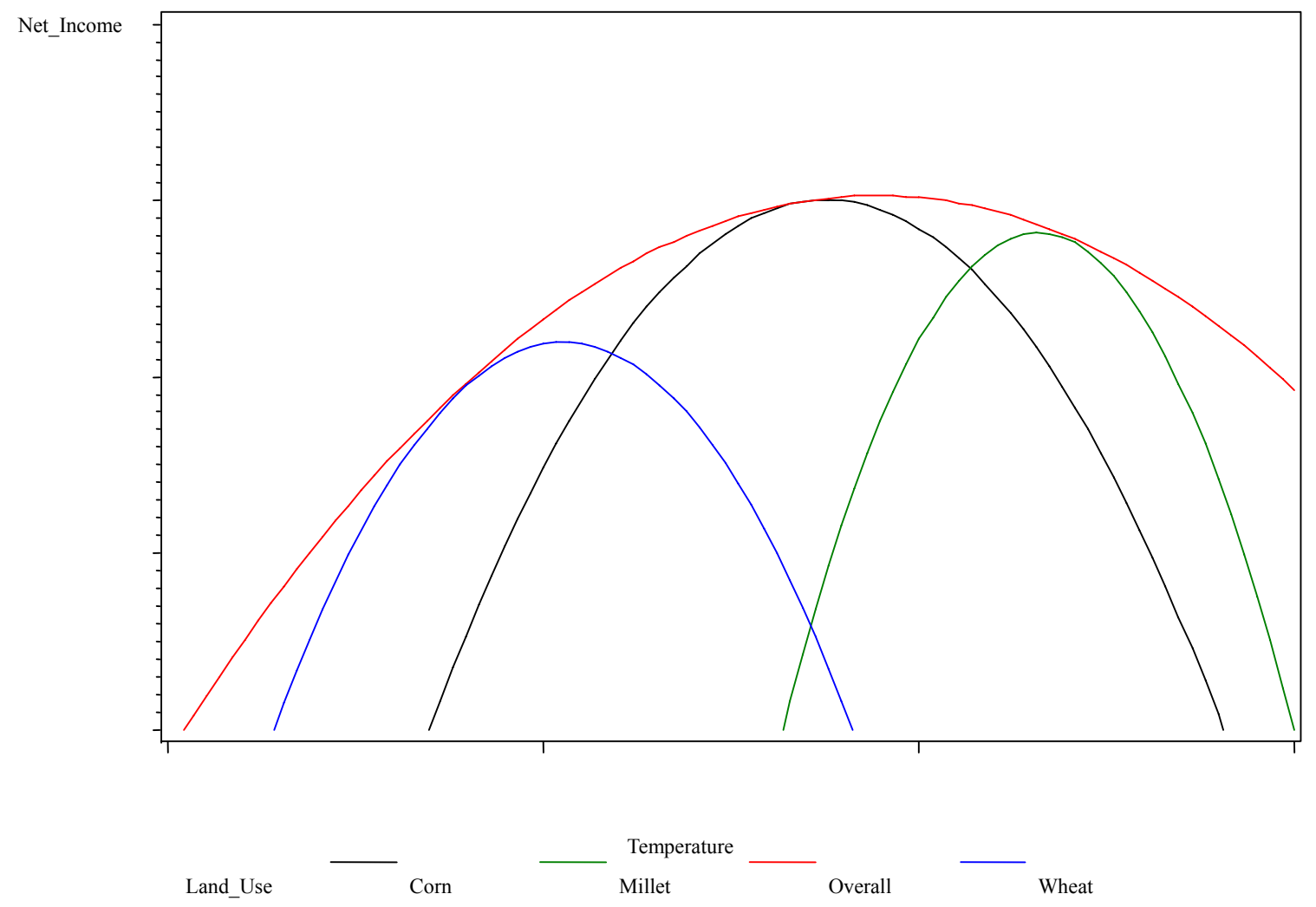


Fig 2a: Estimated Land Value of Small and Large Farms Versus Temperature

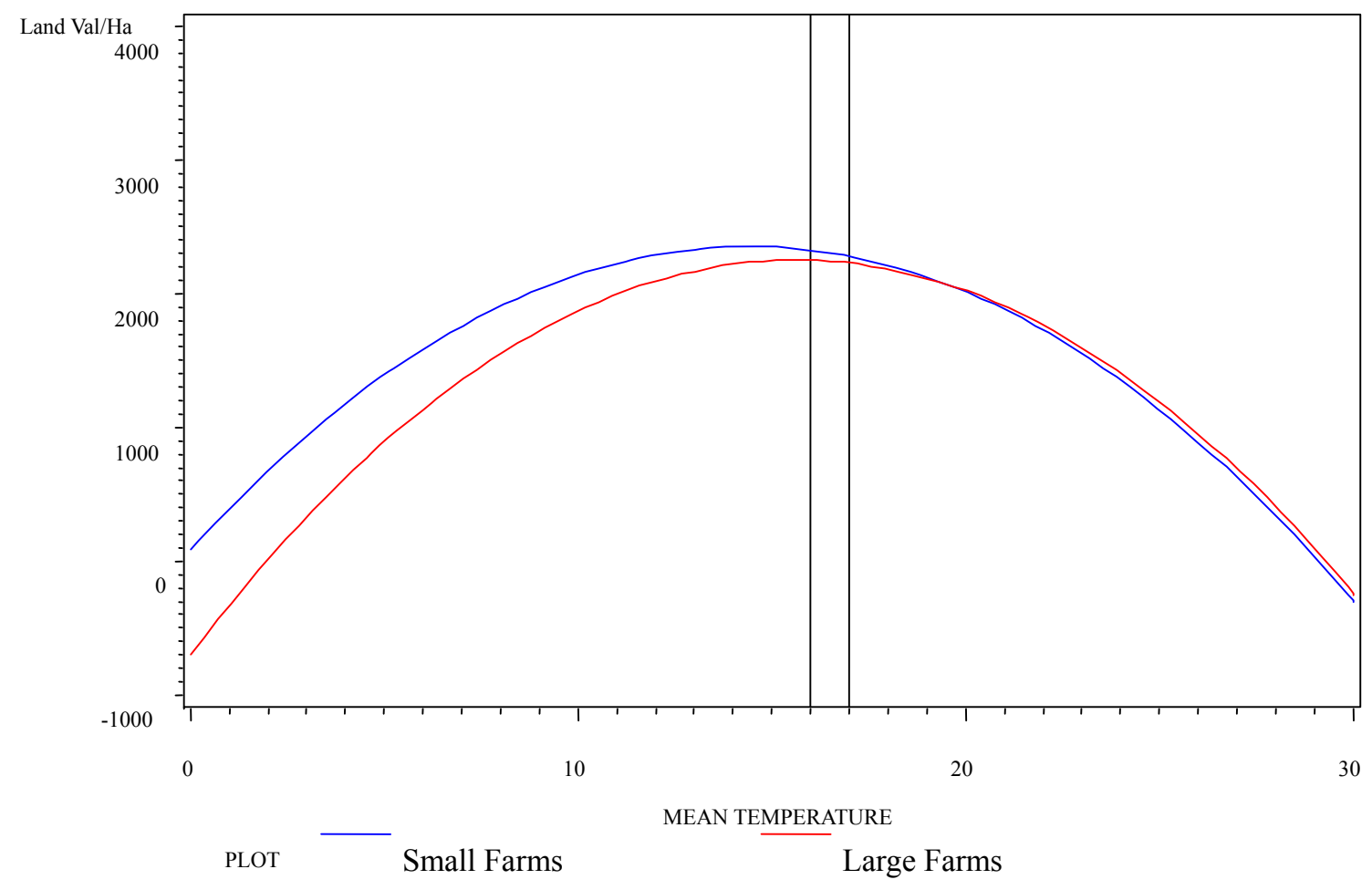


Figure 2b: Estimated Net Revenue of Small and Large Farms Versus Temperature

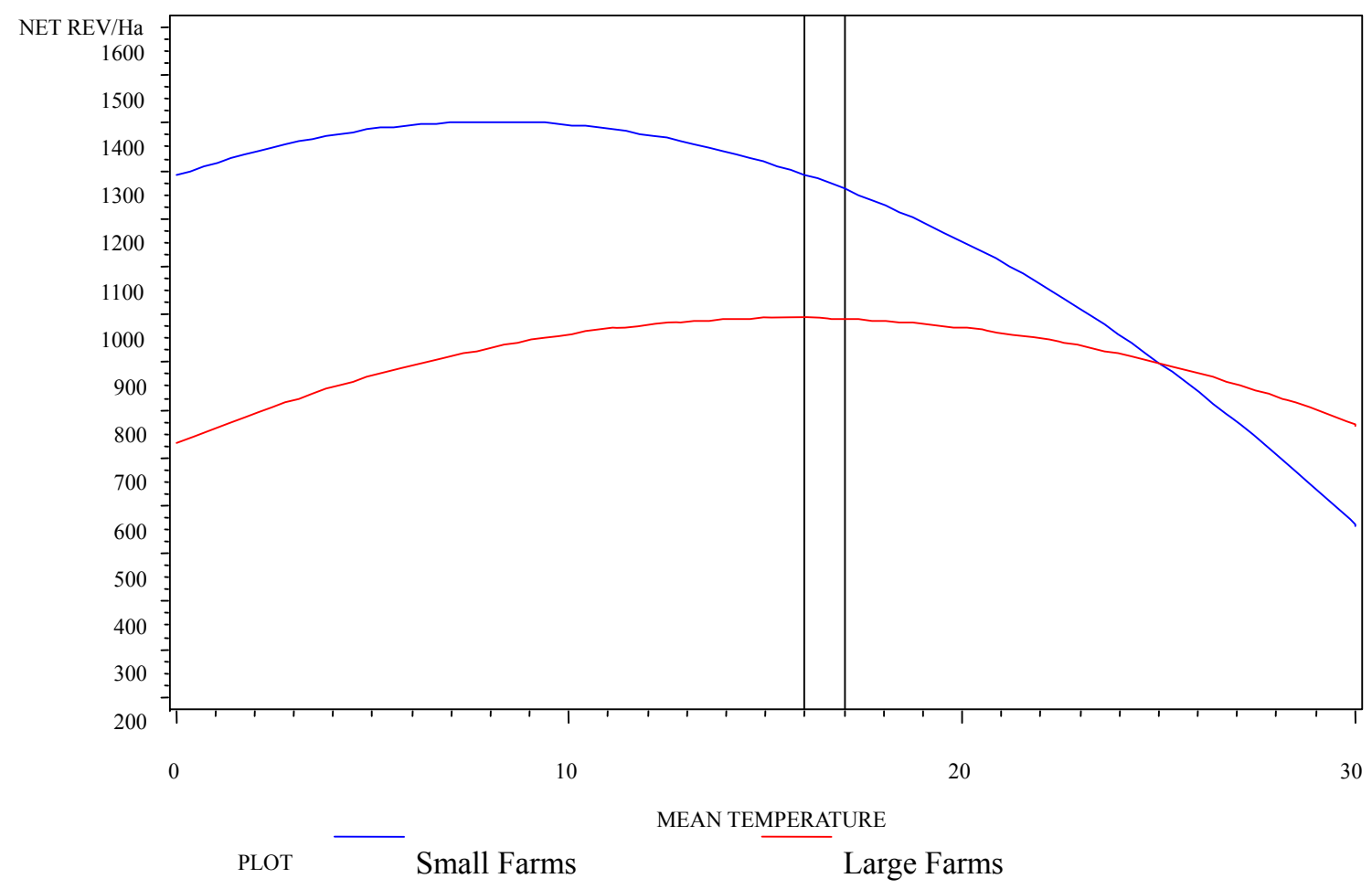


Fig 3a: Estimated Land Value of Small and Large Farms Versus Precipitation

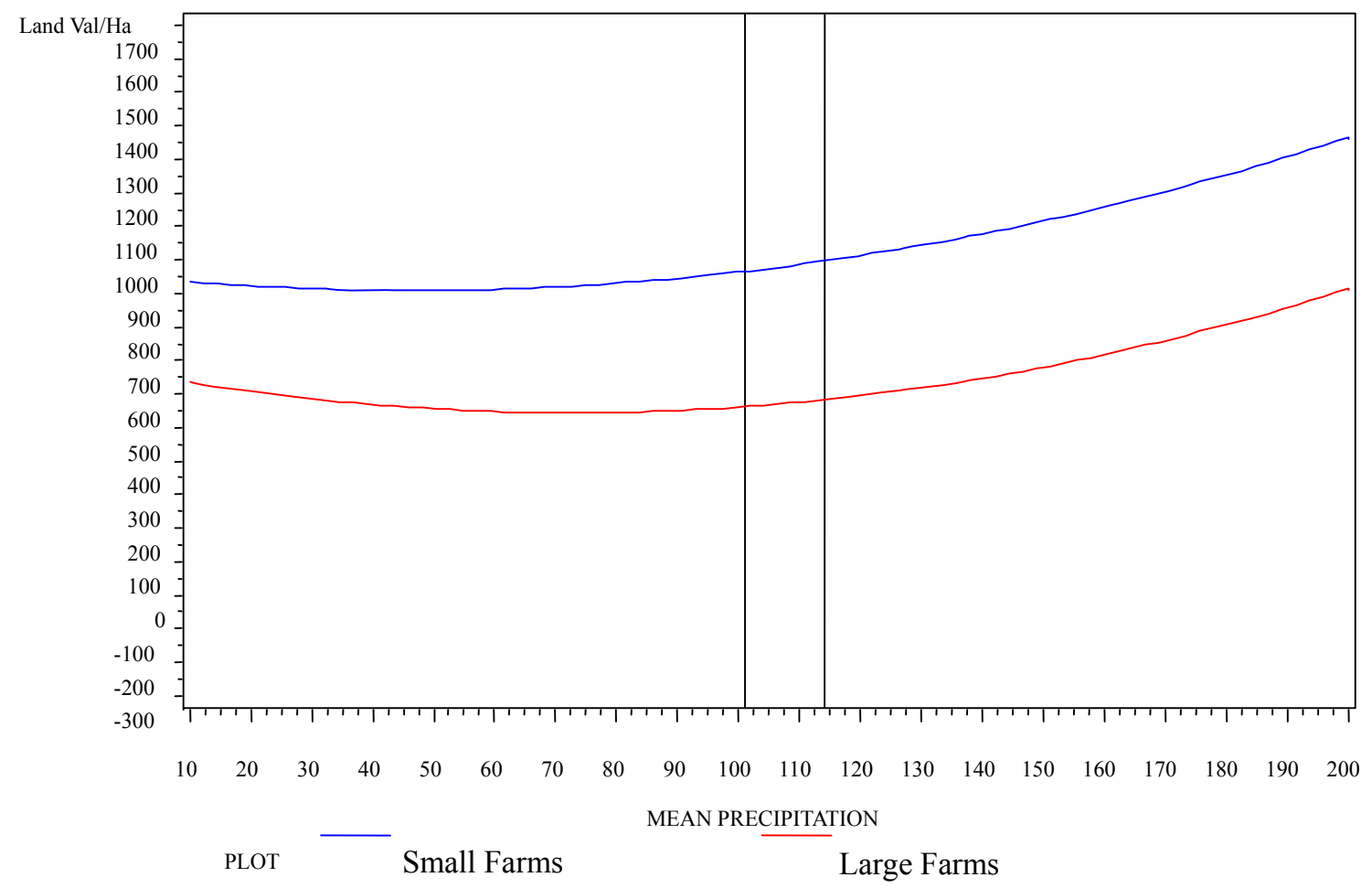


Figure 3b: Estimated Net Revenue of Small and Large Farms Versus Precipitation

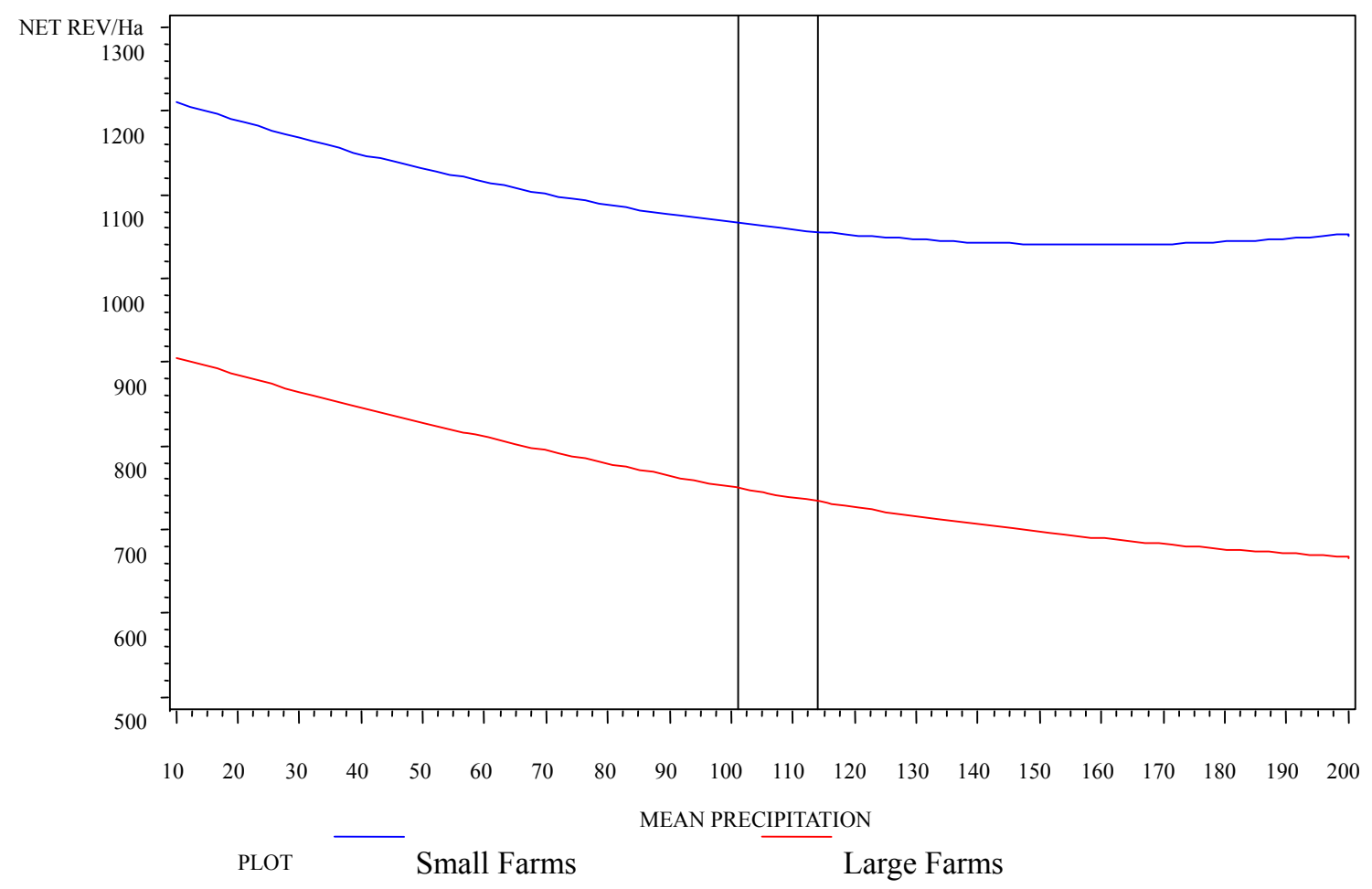


Figure 4a: PCM 2100 for Small Farms

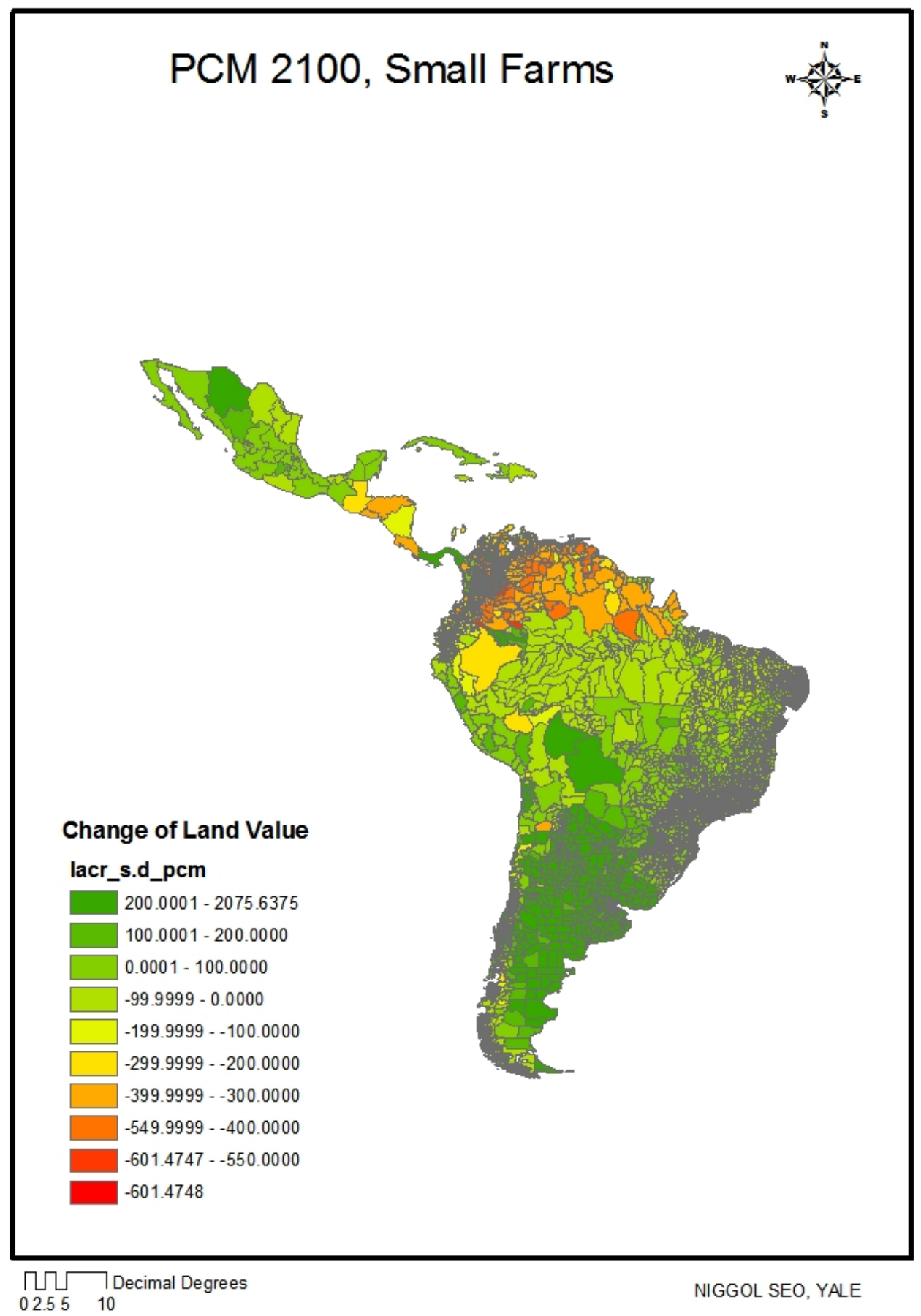


Fig 4b: CCC 2100 for Small Farms

\section{2100, Small Farms}

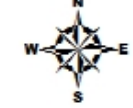

Change of Land Value lacr_s.d_ccc

$200.0001-692.1573$

$100.0001-200.0000$

$0.0001-100.0000$

$\square-99.9999-0.0000$

ए $-199.9999--100.0000$

$-299.9999--200.0000$

$-399.9999--300.0000$

$-549.9999--400.0000$

$-699.9999--550.0000$

$-916.9587--700.0000$ 
Fig 4c: CCSR 2100 for Small Farms

\section{CCSR 2100, Small Farms}

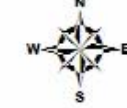

Change of Land Value

lacr_s.d_ccsr

$200.0001-400.0000$

$100.0001-200.0000$

$0.0001-100.0000$

$-99.9999-0.0000$

$-199.9999--100.0000$

$-299.9999--200.0000$

$-399.9999--300.0000$

$-549.9999--400.0000$

$-699.9999--550.0000$

$-854.6450--700.0000$

П口Decimal Degrees

NIGGOL SEO, YALE 
Fig 5a: PCM 2100 for Large Farms

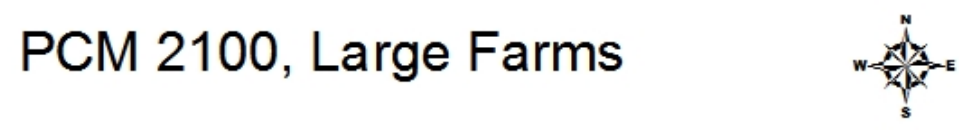

Change of Land Value lacr_B.d_pcm

$200.0001-416.8261$

$100.0001-200.0000$

$0.0001-100.0000$

-99.9999 - 0.0000

$-199.9999--100.0000$

\begin{tabular}{l}
$\square-299.9999--200.0000$ \\
\hline
\end{tabular}

\begin{tabular}{l}
$\square-399.9999--300.0000$ \\
\hline
\end{tabular}

$-549.9999--400.0000$

$-699.9999--550.0000$

$-862.5774--700.0000$
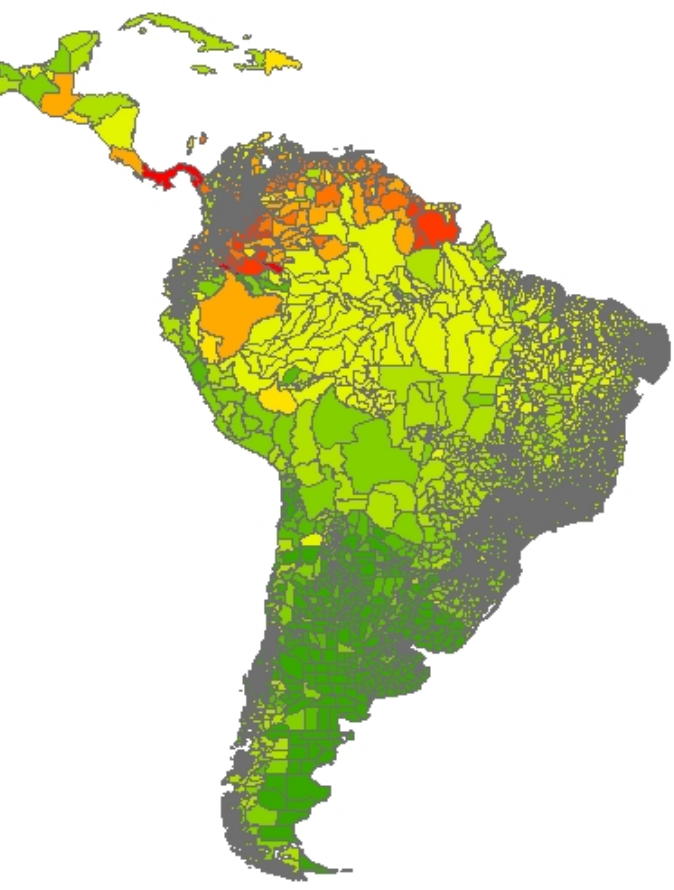

П口 Decimal Degrees $02.55 \quad 10$

NIGGOL SEO, YALE 
Fig 5b: CCC 2100 for Large Farms

\section{2100, Large Farms}

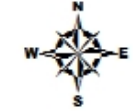

Change of Land Value

lacr_B.d_ccc

$200.0001-481.0093$

$100.0001-200.0000$

$0.0001-100.0000$

$-99.9999-0.0000$

$-199.9999--100.0000$

$-299.9999--200.0000$

$-399.9999--300.0000$

$-549.9999--400.0000$

$-619.2726--550.0000$

$-619.2727$

П\Decimal Degrees

NIGGOL SEO, YALE 
Fig 5c: CCSR 2100 for Large Farms

\section{CCSR 2100, Large Farms}

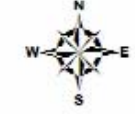

Change of Land Value

lacr_B.d_ccsr

$200.0001-300.0000$

$100.0001-200.0000$

$0.0001-100.0000$

ए $-99.9999-0.0000$

$-199.9999--100.0000$

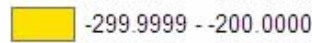

$-399.9999--300.0000$

$-549.9999--400.0000$

$-699.9999--550.0000$

$-745.7259--700.0000$

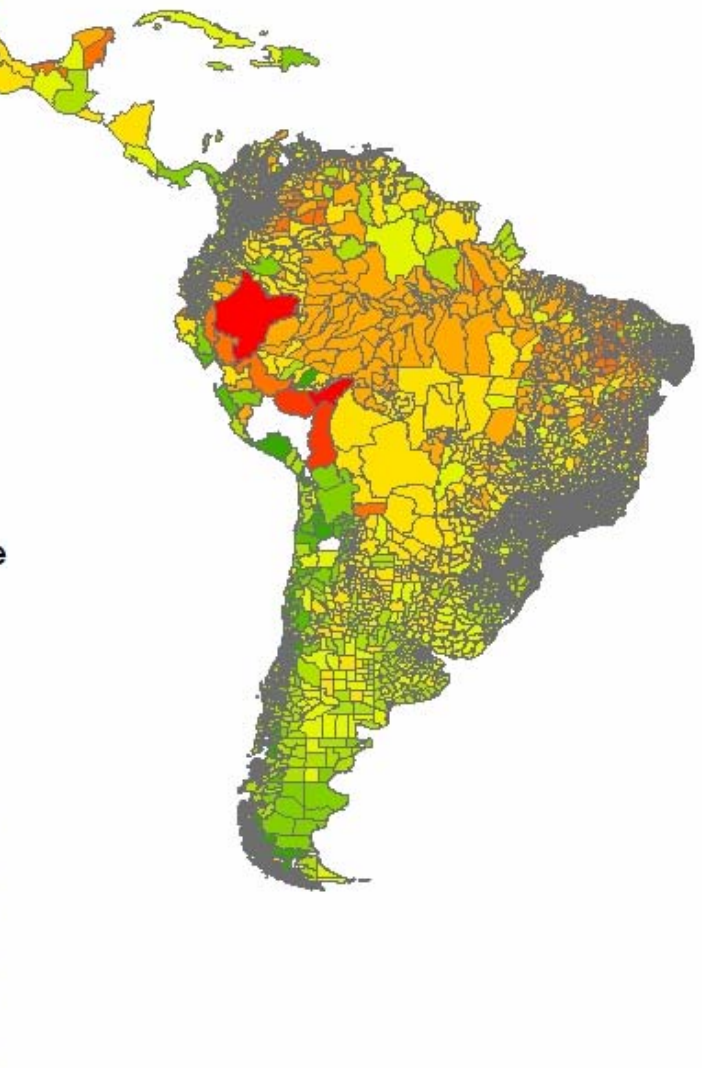

ПपDecimal Degrees

NIGGOL SEO, YALE $02.55 \quad 10$ 